\title{
Accreditation of schools as Health Promoting Schools and Health Profile Assessment of Selected Accredited Schools in a Northern City of India
}

JS Thakur ( $\boldsymbol{\sim}$ jsthakur64@gmail.com )

Post Graduate Institute of Medical Education and Research

Meenakshi Sharma

PGIMER

Bhavneet Bharti

Post Graduate Institute of Medical Education and Research

Rupinder Kaur

Post Graduate Institute of Medical Education and Research

Meenakshi Sharma

Indian Council of Medical Research

Research article

Keywords:

Posted Date: April 14th, 2020

DOI: https://doi.org/10.21203/rs.3.rs-20062/v1

License: (c) (i) This work is licensed under a Creative Commons Attribution 4.0 International License.

Read Full License 


\section{Abstract}

Background: Accreditation is a public recognition of the achievement of required standards by an organization. It certifies the schools for their efforts in implementing health promotion initiatives following an assessment, further helping them in redeveloping and implementing effective HPS strategies.

Methods: The current study was conducted in 206 schools of Chandigarh with the objective of assessment and classification on accreditation level (bronze, silver, gold and platinum levels) as health promoting schools; intervention for one year for further quality improvement and reassessment after one year from 2016-2019. Interventions in the form of capacity building, technical visits, supportive supervision to schools, sensitization of policymakers and key stakeholders, implementation of policy initiatives, use of social media, technical support and monitoring of activities) were provided to all schools. Comparative health profile assessment was undertaken 754 children from higher and 700 children from lower accredited schools by GSHS questionnaire.

Results : Out of 206 schools, 203 participated in the baseline and 204 in endline assessment. The response rate was $99 \%$.Two schools which refused participation were excluded and not assessed. Schools ( $N=17)$ which participated in the 2011-2013 study were excluded from analysis. There was a statistically difference $(p=0.01)$ in the improvement of accreditation level of the baseline and endline assessment $(p<0.05)$. Overall, the proportion of schools at the gold level increased from $1(0.5 \%)$ in 2016 to $71(38 \%)$.Silver level from $9(5 \%)$ to $57(31 \%)$ of schools after intervention. The response rate in health profile assessment in higher and lower accredited schools was $95.9 \%$ and $92.7 \%$ respectively. The health profile higher accreditation level schools $(\mathrm{N}=754)$ were found better in hygiene practices protective factors (peer support at school, parental or guardian supervision), handling stress and less prone to injury as compared to lower accreditation level schools $(N=700),(p<0.05)$.

Conclusions: The schools accreditation was feasible and lead to significant improvement in accreditation level as compared to baseline assessment $(p<0.05)$. The Health profile assessment was also found to be better in higher as compared to lower accredited schools. Therefore, the accreditation system was found to be feasible, effective and beneficial in terms of improving health profile of children in the school setting.

\section{Background}

The health of children and adolescents is of supreme importance to the growth and development of any country. Along with the family, the school is one of the main settings in which individual and social development occur [1]. The interaction between school teachers and students provides a unique opportunity for health promotion that can be sustained and reinforced over time[2]. Hence, school is an appropriate setting to improve youth health. 
The "Health Promoting School" (HPS) is a holistic approach to integrate health promotion within the community. The concept of 'Health Promoting Schools' was adopted by the World Health Organization (WHO) in 1995, as part of a settings-based approach to health improvement. In Europe, North America, and the Western Pacific region, there have been significant developments in the promotion of children's health involving schools[3].

In India, a pilot activity for accreditation of 'Health promoting schools' was undertaken under the umbrella of WHO, Health Department of Chandigarh, Ministry of Health \& Family Welfare, ICMR, Quality Council of India and Principals of School at Chandigarh in 2010-11 in which a checklist and scoring indicators were developed and 17 schools were assessed and accreditated[2].

Accreditation is a public recognition of the achievement of required standards by an organization. [4] It certifies the schools for their efforts in implementing health promotion initiatives following an assessment, further helping them in redeveloping and implementing effective HPS strategies. Four categories of accreditation were formulated namely, Platinum, gold, silver, and bronze in the pilot study [2].

The current study was conducted to assess and classify all private and government schools located in Chandigarh for accreditation as health promoting schools and comparative health profile assessment of selected accredited schools under the project funded by Indian Council of Medical Research.

\section{Methods}

The present study was a quasi-experimental conducted in 206 schools (public and private) in Chandigarh city from September 2016 till May 2019. Meeting with key stakeholders viz Education Secretary and Director Public Instructions, School health program officer, Chandigarh Administration were held for ensuring their active participation and permission was taken for the study. Sensitization and training of cluster resource centre coordinators (CRCCs) from Education Department, Chandigarh Administration were held. Each CRCC deals with 4-6 schools located in the area designated to them.

Manual developed in an earlier pilot study (2011-2013) was reviewed and accreditation checklist in the manual was modified in order to assess 8 domains: (Healthy School Environment, Mechanism for promoting health in schools, School health services, School nutrition services, Physical Education, School counseling, psychological and social services, Community partnership, Implementation of Shala Siddhi and mentoring schools in becoming HPS ). Cut-off scores for bronze, silver, gold, and platinum levels are categorized as 100-120,121-150, 151-200 and > 200 points, respectively, as per the standards developed in the previous study. [2]

Two training workshops were conducted to train the assessors in understanding the process of assessment and accreditation of schools as HPS. After the consent of school authorities, the assessment date was scheduled as per the convenience of school authorities. For baseline assessment, a team of 34 assessors was constituted for carrying out assessment activities in each school. A brief introduction 
session was held with school authorities before beginning the assessment. Documentation verification was conducted, followed by a physical assessment of the school infrastructure. Debriefing sessions with school authorities were conducted at the end of the assessment.

Key school-based interventions for a period of 1 year (2017-2018) included zone wise division of all schools of the Chandigarh into three zones consisting of approximately 70 schools each: East, South and Central for providing technical support. After distribution of feedback reports on baseline assessment by zone coordinators to the schools; social media groups of respective zones were created. Orientation and reorientation workshops for principals and teachers, convergence with other National health programs like Rashtriya Bal Swasthya Karyakram(RBSK)/Rashtriya Kishor Swasthya Karyakram(RKSK), school health program, mid-day meal and implementation of policy initiatives was done. Investigators coordinated with schools for mentoring of other schools; higher accredited schools on the basis of baseline assessment were encouraged to help lower accredited schools for which means of communication (exchange of contact details) was established between them. Investigators and key stakeholders also visited $10 \%$ of the schools for monitoring and supervision. Endline assessment was undertaken from October 2018 -March 2019 onwards.

The health profile assessment of school children from classes 7 and 8 in the eight (4 government and 4 private) higher accredited schools were compared with children of eight (4 government and 4 private) lower accredited. The health profile was studied by a questionnaire based on the adapted CBSE Indian version of questionnaire of Global School-based Student Health Survey-2007 with a focus on modules on diet, physical activity, tobacco use, alcohol use, drug use, mental health, hygiene, protective factors, violence and unintentional injury and sexual behavior modules. The schools were randomly selected from the list of higher and lower accredited school. Only those students were covered who were available in the school on the scheduled day after obtaining written parental consent and the child's assent. The students were required to complete the questionnaires independently in 90 minutes ( 2 class periods).

Ethical permission for conduction of study was taken from the institutional ethics committee.

\section{Data analysis:}

The data collected was entered in excel spreadsheet and analyzed by using SPSS ver 20 and Epi info. Initially, the data was screened for missing and outliers. Descriptive statistics was used to describe the study demographics using frequencies (n), percentages (\%), means, and standard deviation (SD). Chisquare was used to examine differences among variables.

\section{Results}

All schools in Chandigarh city $(\mathrm{N}=206)$ were invited for participation in the study of the ICMR funded project. Out of 206 schools, 203 participated in the baseline assessment and 204 in the endline assessment. Two schools which refused participation were excluded and not assessed. The response rate was $99 \%$. Schools $(N=17)$ which participated in the $2011-2013$ study were excluded from analysis 
[2]. Data of government schools $(N=113)$ and private schools $(N=74)$ was analyzed. Distribution of schools showed that there were more high schools (49\%) as compared to senior secondary schools (32\%) among government category(table-1). Overall, there were more senior secondary schools as compared to other education levels in the private category. The median of toilet ratio for boys was 28.9(Inter Quartile Range $(I Q R)=20-73)$ in the Government and $23(16-39)$ in the private schools in 2018(table-1).

Table 2 depicted that one hundred fifty two (82\%) schools were below bronze level during the baseline assessment but after intervention the schools in the same level reduced to $25(13 \%)$ i.e. $16(14 \%)$ government and $9(12 \%)$ private schools respectively which was found to be significant $(p=0.001)$. The proportion of schools acquiring silver accreditation increased from $9(5 \%)$ to $57(31 \%)$ of schools $(p=$ 0.001). Overall, the proportion of schools at the gold level increased from 1(0.5\%) in 2016 to $71(38 \%)$ in 2018 which was found to be significant $(p<0.05)$.

The proportion of schools with school safety, security and presence of evacuation plan increased from 99(54\%) in 2016 to 172(92.5\%) in 2018(Table - 3). The presence of a School Health Committee (SHC) had significantly improved from $134(72 \%)$ of schools in 2016 , compared with 178 ((95.7\%) of schools in $2018(p=0.02)$. Training for the HPS program in schools increased from $112(61 \%)$ in 2016 to $165(89 \%)$ in $2018(p=0.004)$. The monitoring of canteens in schools for ensuring quality improved from $68 \%$ in 2016 to $99 \%$ in $2018(P=0.02)$. All schools included in the study were found to have appropriate playground facilities except 5 Government schools and 2 private schools. In 2018, it was found that 178 (96\%) of them had designated hours each week assigned for physical activity (Physical activity sessions (PT period) of 45 minutes per day for all days (minimum 5 days)) compared with 167(90\%) in 2016(Table-3).

Health profile of students from 8 higher accreditation schools (gold, silver) were compared in the lower ( below bronze) accreditation schools with 754 children from higher and 700 from lower accreditation levels were selected for further health assessment. The response rate in higher and lower accredited was $95.9 \%$ and $92.7 \%$ respectively. There was no significant difference between demographic characteristics of participants of higher and lower accredited schools. There was no difference as per gender among higher and lower accredited schools $(p=0.14)$. Among all the participants, majority of the students were in the age group $11-13$ years i.e. $83 \%$ and $81 \%$ among government and private schools respectively.

Hygiene practices were better among students of higher accredited schools as compared to students of lower accredited schools (Table-4). More than $87 \%$ and $92 \%$ students from higher accredited schools reported that they washed their hands before eating and after toileting respectively as compared to lower accredited schools $(p=0.04)$.

Protective factors including peer support at school, parental or guardian supervision were found to significantly better among students of higher accredited schools $(p=0.005, p=0.04)$. In relation to parents' or guardians' monitoring, $62 \%$ students of higher accredited schools reported approved parental control for observation on their free-time activities. 
More than 63\% students from higher accredited schools reported that they were taught to handle stress in healthy ways as compared to $55 \%$ children in lower accreditation level during school year $(p=0.003)$. The majority $(66 \%)$ from lower accredited schools claimed they had serious injury happened to them in the past 12 months as compared to $62 \%$ higher accreditation level $(p=0.077)$.

About 20\% students from higher accredited schools reported that parents or guardians drink alcohol as compared to $16 \%$ students from lower accredited schools $(p=0.05)$.

Students from lower accredited schools were more informed regarding HIV $(36 \%)$ than those from higher accredited schools(46\%). Knowledge regarding neatly looking person can be HIV infected was more in lower accredited schools children (30.42\%) as compared to higher accredited school children (23.07\%).It was found that students from lower accredited schools (30\%) were more aware about HIV as compared to students from higher accredited schools $(23 \%)(p=0.001)$.

\section{Discussion}

School settings have long been recommended as an excellent health promoting settings. Studies have reported that evidence-based interventions in the school setting should be promoted as an important component for integrated programs, policies, and monitoring frameworks designed to reverse the childhood obesity in the region[5].Based on the multifaceted nature of the HPS, evaluation of the schools is a challenge due to broad concept [6].Hence the accreditation system, a practical tool to implement HPS was used in present study for assessment and classification of all government and private schools of Chandigarh city(2). The accreditation scheme has been implemented only in Thailand in the South East Asia region. In India, Chandigarh has become the first city to have undergone accreditation of all schools as HPS. Accreditation is a voluntary and continuous quality improvement process under different parameters. For self-improvement relevant school based interventions were provided in the current study. On achieving particular accreditation level, sustainability and ambition to move to the next level becomes the objective of a particular school. Nevertheless, for sustainability, continuous active participation of the key stakeholders and commitment by school administration is required [7].

Study conducted in Hong Kong found that students in HPSs had a more positive health behavior profile as compared to those in non-HPS[8].A review evaluating nine studies of HPS emphasized that HPS has some influence on various domains of health for the school community[9]. Another study highlighted there is scope for integrating health promotion into school policies and the curriculum[10]. A multicomponent model of nutrition and lifestyle education was found to be effective in improving the nutritionrelated knowledge, lifestyle practices, and resulted in beneficial changes in anthropometric and biochemical profiles of the Asian Indian adolescents[11].

In the current study, it was observed that knowledge and practices of personal hygiene of students studying in higher accredited schools were finer than students of lower accredited schools. A study reported that low awareness about personal hygiene were the key areas of concern and could be tackled by the active involvement of school teachers, bringing about improvement in personal hygiene of school 
children[12].Personal hygiene, mental health have been identified as priority areas for HPS .Hence students of higher accredited schools in the present study were more attentive to their personal hygiene and also taught to handle stress in schools.

Our study demonstrated that Shaala Siddhi has been implemented in government schools as compared to private schools. Shaala Siddhi is a national programme on school standards and evaluation[13]. It is a school self-evaluation process in a sequential manner and particularly domains 1, 5,6, 7 i.e enabling resources of the school, school leadership and management, inclusion, health and safety, and productive community participation are related to HPS.

Our study showed that community partnership in decision-making and planning in the health-promoting activities improved after one year of intervention in the current study. The HPS concept highlights community participation as integral to the success of health-promoting interventions. Studies have reported that ownership, leadership, and collaboration are critical to improving school health. (14) If schools formally or informally create numerous interagency partnerships in the community students, families, and other community members can be engaged for participation in HPS.

Students from lower accredited schools were more informed about sexual behaviour module. Most of the lower accredited schools were in the periphery area of the Chandigarh city, considered at higher risk for the prevalence of HIV which are covered under targeted interventions (TI project). Hence the frequency of interventions on HIV might be more in these schools.

The higher accreditation schools were found better in hygiene practices, protective factors (peer support at school, parental or guardian supervision), handling stress, and less prone to injury as compared to lower accreditation level schools.

Hence, it is recommended that the assessment for accreditation should be carried out in all school settings in other parts of India and accreditation certification to be awarded. Hand holding support should be provided to schools for further improvement in accreditation levels. The assessment and classification of accreditation levels for establishing health promotion model in school settings is feasible and must be integrated into the school education system.

\section{Conclusions}

Health promoting schools interventions should be undertaken for enhancing accreditation levels. The study also concluded that there was a difference between various modules of health profile assessment like hygiene, mental health among higher and lower accredited schools. Hence accreditation of schools as HPS should be conducted on a periodic basis for further improvement and should be upscaled to the National level.

\section{Abbreviations}


Health Promoting School (HPS), World Health organization (WHO), cluster resource centre coordinators (CRCCs), School Health Committee (SHC)

\section{Declarations}

\section{Ethics approval and consent to participate}

Ethical permission for conduction of study was taken from the institutional ethics committee of Post Graduate Institute of Medical Education and Research.Written parental consent and the child's assent were obtained for health profile assessment

\section{Consent for publication}

Not applicable

\section{Availability of data and materials}

The datasets during and/or analysed during the current study available from the corresponding author on reasonable request.

\section{Competing interests}

The authors declare that they have no competing interests. This is to inform that Prof JS Thakur is an Editorial Board Member

\section{Funding}

The study has been conducted under the project funded by Indian Council of Medical Research. Funding was provided for conducting the study, salaries of the project staff, travel and contingency grant. But no funding assistance was provided for publications of the manuscript.

Authors' contributions: All authors have read and approved the manuscript

Prof JS had substantial contributions to the conception, design of the work; the acquisition, analysis, interpretation of data; drafted the work; substantively revised it and approved the submitted version

MS had role in data collection, analysis, interpretation of data; drafted the work, substantively revised it and approved the submitted version

BB contributed in design of the work, analysis, interpretation of data; drafted the work; revision and approved the submitted version

RK was involved in data collection, drafted the work; substantively revised it and approved the submitted version 
MS had substantial contributions to the conception, design of the work; the acquisition, revision and approved the submitted version

\section{Acknowledgements}

We acknowledge the contributions of HPS project staff who provided general support.

\section{References}

1. Lee A. Can Health Promoting Schools contribute to the better health and wellbeing of young people? The Hong Kong experience. J Epidemiol Community Heal. 2006;60:530-6.

2. Thakur JS, Sharma D, Jaswal N, Bharti B, Grover A, Thind P. Developing and implementing an accreditation system for health promoting schools in Northern India: a cross-sectional study. BMC Public Health. 2014;14:1314.

3. St Leger LH. The opportunities and effectiveness of the health promoting primary school in improving child health a review of the claims and evidence. Health Educ Res. 1999;14:51-69.

4. Mate KS, Rooney AL, Supachutikul A, Gyani G. Accreditation as a path to achieving universal quality health coverage. Global Health. 2014;10:68.

5. Lobelo F, Garcia de Quevedo I, Holub CK, Nagle BJ, Arredondo EM, Barquera S, et al. School-based programs aimed at the prevention and treatment of obesity: evidence-based interventions for youth in Latin America. J Sch Health. 2013;83:668-77. doi:10.1111/josh.12080.

6. Inchley J, Muldoon J, Currie C. Becoming a health promoting school: evaluating the process of effective implementation in Scotland. Health Promot Int. 2007;22:65-71.

7. Thakur J, PGIMER. Manual for Accreditation of HPS. 2019.

8. Lee A, Wong MCS, Keung VMW, Yuen HSK, Cheng F, Mok JSY. Can the concept of Health Promoting Schools help to improve students' health knowledge and practices to combat the challenge of communicable diseases: Case study in Hong Kong? BMC Public Health. 2008;8:1-8.

9. Mũkoma W, Flisher AJ. Evaluations of health promoting schools: a review of nine studies. Health Promot Int. 2004;19:357-68. doi:10.1093/heapro/dah309.

10. Mclsaac JLD, Penney TL, Ata N, Munro-Sigfridson L, Cunningham J, Veugelers PJ, et al. Evaluation of a health promoting schools program in a school board in Nova Scotia, Canada. Prev Med Reports. 2017;5:279-84. doi:10.1016/j.pmedr.2017.01.008.

11. Singhal N, Misra A, Shah P, Gulati S. Effects of controlled school-based multi-component model of nutrition and lifestyle interventions on behavior modification, anthropometry and metabolic risk profile of urban Asian Indian adolescents in North India. Eur J Clin Nutr. 2010;64:364-73.

12. Jamra V, Bankwar V, Saxena MD. A Comparative Study of Basic Health Service Provided in Government and Private Schools of Bhola City. Natl J Community Med. 2014;5:131-4.

13. Shaala Siddhi. http://shaalasiddhi.niepa.ac.in/. Accessed 8 Mar 2020. 
14. Chen FL, Lee A. Health-promoting educational settings in Taiwan: development and evaluation of the Health-Promoting School Accreditation System. Glob Heal Promot. 2016;23 1 Suppl:18-25.

\section{Tables}

Table 1: Distribution and key characteristics of Government and Private Schools in Chandigarh (2016-2018)

\begin{tabular}{|c|c|c|}
\hline \multirow[t]{2}{*}{ Category } & Government $(\mathrm{N}=113)^{*}$ & \multirow{2}{*}{$\begin{array}{c}\text { Private }(\mathrm{N}=74) \\
\mathrm{n}(\%)\end{array}$} \\
\hline & n (\%) & \\
\hline \multicolumn{3}{|l|}{ Education levels } \\
\hline Senior Secondary & $37(32.74)$ & $43(58.10)$ \\
\hline High & $55(49.11)$ & $12(16.21)$ \\
\hline Middle & $13(11.61)$ & $9(12.16)$ \\
\hline Primary & $8(7.14)$ & $10(13.51)$ \\
\hline \multicolumn{3}{|c|}{ Characteristics $\quad$ Median(IQR) } \\
\hline Girls & $530(305-820)$ & 424(192-707) \\
\hline Boys & $588(336-880)$ & $559(226-920)$ \\
\hline Water consumption person per day & $17(11-23.98)$ & $16(10-32.15)$ \\
\hline Toilet ratio-Boys & $28.9(20-73)$ & $23(16-39)$ \\
\hline Toilet ratio-Girls & $41.5(26.6-56)$ & $30(18-42)$ \\
\hline Student tap ratio & $52(38.6-85.7)$ & $50(36.9-79.75)$ \\
\hline
\end{tabular}

*One new Govt school was functional in 2018. Figures in parenthesis are percentages

Table 2: Comparison of Accreditation levels of Government and Private Schools in Chandigarh after one year of intervention (2016-2018)

\begin{tabular}{|c|c|c|c|c|c|c|c|c|}
\hline & \multicolumn{3}{|c|}{ Pre Intervention } & \multicolumn{3}{|c|}{ Post Intervention } & & \\
\hline Category & $\begin{array}{c}\text { Government schools } \\
(\mathrm{N}=112) \\
\mathrm{n}(\%)\end{array}$ & $\begin{array}{c}\text { Private schools } \\
(\mathrm{N}=74) \\
\mathrm{n}(\%)\end{array}$ & $\begin{array}{c}\text { Total } \\
(\mathrm{N}=186) \\
\mathrm{n}(\%)\end{array}$ & $\begin{array}{l}\text { Government schools } \\
(\mathrm{N}=113) \\
\mathrm{n}(\%)\end{array}$ & $\begin{array}{l}\text { Private schools } \\
(\mathrm{N}=74) \\
\mathrm{n}(\%)\end{array}$ & $\begin{array}{l}\text { Total } \\
(\mathrm{N}=187) \\
\mathrm{n}(\%)\end{array}$ & $\begin{array}{l}\% \text { age } \\
\text { Change }\end{array}$ & \begin{tabular}{|l|}
$P$ \\
value
\end{tabular} \\
\hline Platinum & 0 & 0 & 0 & 0 & $2(2.74)$ & $2(1.08)$ & +1.08 & . \\
\hline Gold & 0 & $1(0.89)$ & $1(0.54)$ & $39(34.51)$ & $32(43.84)$ & 71(38.17) & +37.63 & $0.001 *$ \\
\hline Silver & $5(4.46)$ & $4(3.57)$ & $9(4.84)$ & $39(34.51)$ & 18(24.66) & $57(30.65)$ & +25.81 & 0.001 \\
\hline Bronze & 15(13.39) & $9(8.03)$ & $24(12.90)$ & $19(16.81)$ & 13(17.81) & $32(17.20)$ & +4.3 & 0.32 \\
\hline Below bronze & 92(82.14) & 60(53.57) & $152(81.72)$ & 16(14.16) & $9(12.1)$ & $25(13.30)$ & -68.42 & 0.001 \\
\hline
\end{tabular}

*pvalue, $\mathrm{X}^{2}$

Table 3: Comparison of government and private Schools as per domains of school health criteria for accreditation in Chandigarh after intervention (score $\geq 3$ ) 


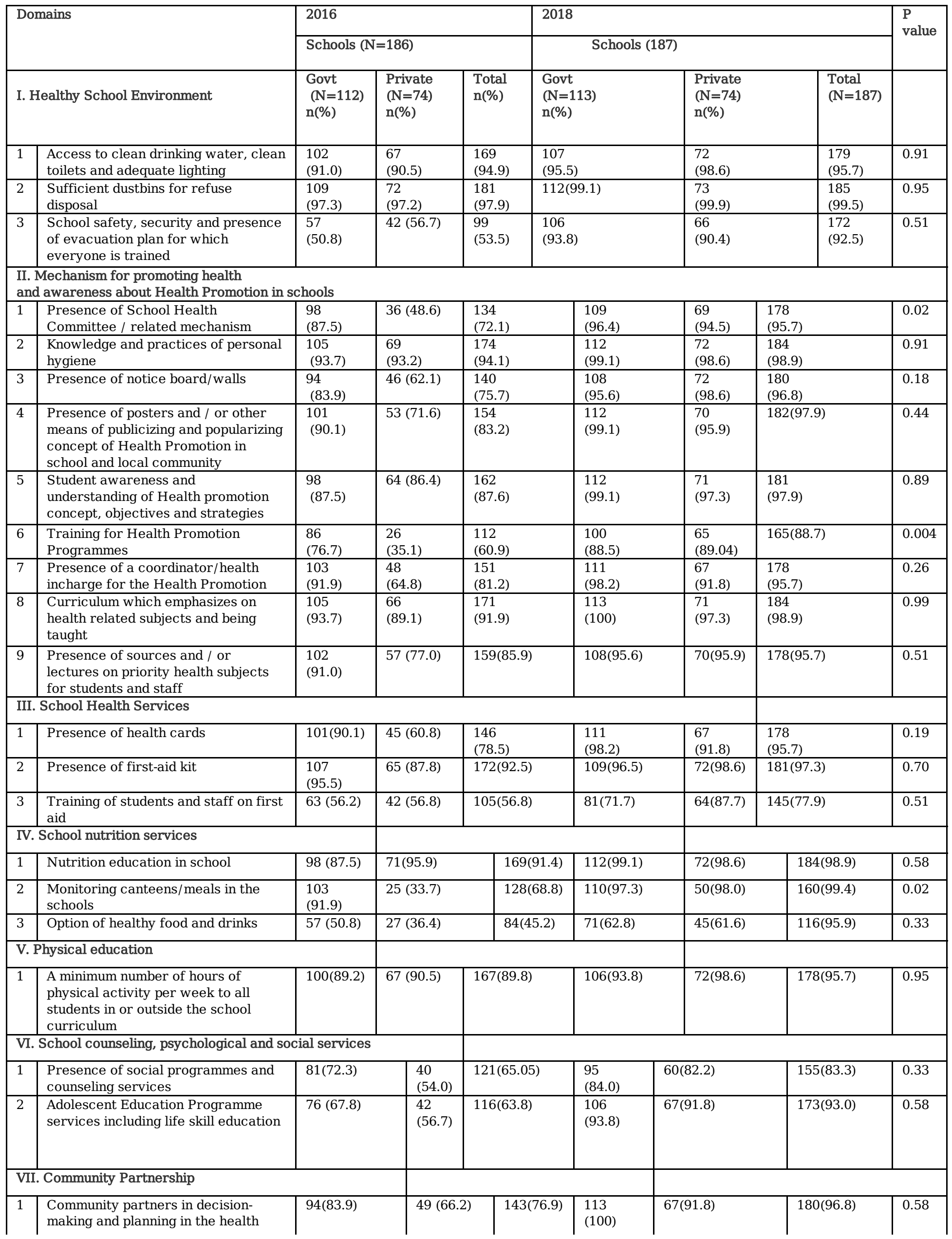


promoting activities of the school

$|\quad|$

$|+|$

VIII. Extent of implementation of School standards and evaluation framework (Shaala Siddhi) and involvement in establishing more Health Promoting Schools and their accreditation

\begin{tabular}{|l|l|l|l|l|l|l|l|}
\hline 1 & $\begin{array}{l}\text { Extent of implementation of SHAALA } \\
\text { SIDDHI as per checklist }\end{array}$ & $91(81.2)$ & $6(8.1)$ & $97(52.4)$ & $101(89.4)$ & $8(10.9)$ & $109(90.2)$ \\
\hline 2 & $\begin{array}{l}\text { Promoting and Assisting in the } \\
\text { accreditation of other schools } \\
\text { (Applicable in Midline or End line } \\
\text { assessment). }\end{array}$ & 0 & 0 & 0 & $15(13.39)$ & $9(12.3)$ & $24(12.9)$ \\
\hline
\end{tabular}


Table4: Comparison of health profile of school children in higher and lower accreditation schools in Chandigarh

Results for students aged 11-16 years

\begin{tabular}{|r|r|r|}
\hline \multicolumn{3}{|c|}{ Higher Accredited Schools } \\
\hline Total & Boys & Girls \\
N(754) & N(399) & N(355) \\
$\mathrm{n} \%$ & $\mathrm{n} \%$ & $\mathrm{n} \%$ \\
& & \\
\hline
\end{tabular}

Lower Accredited School

\begin{tabular}{r|} 
Total \\
$\mathrm{N}(700)$ \\
$\mathrm{n} \%$
\end{tabular}

Dietary Behaviors and Overweight

\begin{tabular}{|c|c|c|c|c|c|c|c|}
\hline $\begin{array}{l}\text { Students who went hungry most of the time or always during } \\
\text { the past } 30 \text { days }\end{array}$ & $\begin{array}{r}45 \\
(5.96 \%) \\
\end{array}$ & $\begin{array}{r}23 \\
(5.77 \%) \\
\end{array}$ & $\begin{array}{r}22 \\
(6.19 \%) \\
\end{array}$ & $\begin{array}{r}55 \\
(7.85 \%) \\
\end{array}$ & $\begin{array}{r}24 \\
(6.13 \%) \\
\end{array}$ & $\begin{array}{r}31 \\
(10.03 \%) \\
\end{array}$ & 0.154 \\
\hline \multicolumn{8}{|c|}{ BMI } \\
\hline $\begin{array}{l}\text { Students who were underweight (<-2SD from median for BMI } \\
\text { by age and sex) }\end{array}$ & $\begin{array}{r}98 \\
(12.99 \%)\end{array}$ & $\begin{array}{r}55 \\
(13.78 \%)\end{array}$ & $\begin{array}{r}43 \\
(12.11 \%)\end{array}$ & $\begin{array}{r}68 \\
(9.71 \%)\end{array}$ & $\begin{array}{r}47 \\
(12.02 \%)\end{array}$ & $\begin{array}{r}21 \\
(6.79 \%)\end{array}$ & 0.242 \\
\hline $\begin{array}{l}\text { Students who were overweight (>+1SD from median for BMI } \\
\text { by age and sex) }\end{array}$ & $\begin{array}{r}103 \\
(13.66 \%) \\
\end{array}$ & $\begin{array}{r}58 \\
(14.53 \%) \\
\end{array}$ & $\begin{array}{r}45 \\
(12.67 \%) \\
\end{array}$ & $\begin{array}{r}107 \\
(15.2 \%) \\
\end{array}$ & $\begin{array}{r}65 \\
(16.62 \%) \\
\end{array}$ & $\begin{array}{r}42 \\
(13.59 \%) \\
\end{array}$ & 0.253 \\
\hline $\begin{array}{l}\text { Students who were obese ( }>+2 \text { SD from median for BMI by } \\
\text { age and sex) }\end{array}$ & $\begin{array}{r}40 \\
(5.30 \%) \\
\end{array}$ & $\begin{array}{r}25 \\
(6.26 \%) \\
\end{array}$ & $\begin{array}{r}15 \\
(4.22 \%) \\
\end{array}$ & $\begin{array}{r}53 \\
(7.57 \%) \\
\end{array}$ & $\begin{array}{r}32 \\
(8.18 \%) \\
\end{array}$ & $\begin{array}{r}21 \\
(6.79 \%) \\
\end{array}$ & 0.969 \\
\hline \multicolumn{8}{|c|}{ Hygiene } \\
\hline Students who brushed their teeth 2 times per day & $\begin{array}{r}417 \\
(55.30 \%)\end{array}$ & $\begin{array}{r}211 \\
(52.88 \%)\end{array}$ & $\begin{array}{r}206 \\
(58.02 \%)\end{array}$ & $\begin{array}{r}383 \\
(54.71 \%)\end{array}$ & $\begin{array}{r}211 \\
(53.96 \%)\end{array}$ & $\begin{array}{r}172 \\
(55.66 \%)\end{array}$ & 0.822 \\
\hline $\begin{array}{l}\text { Students who always or most of time washed their hands } \\
\text { before eating }\end{array}$ & $\begin{array}{r}658 \\
(87.26 \%)\end{array}$ & $\begin{array}{r}352 \\
(88.22 \%)\end{array}$ & $\begin{array}{r}306 \\
(86.19 \%)\end{array}$ & $\begin{array}{r}585 \\
(83.57 \%)\end{array}$ & $\begin{array}{r}329 \\
(84.14 \%)\end{array}$ & $\begin{array}{r}256 \\
(82.84 \%)\end{array}$ & 0.045 \\
\hline $\begin{array}{l}\text { Students who always or most of time washed their hands } \\
\text { after using the toilet/latrine }\end{array}$ & $\begin{array}{r}701 \\
(92.97 \%) \\
\end{array}$ & $\begin{array}{r}372 \\
(92.48 \%) \\
\end{array}$ & $\begin{array}{r}329 \\
(91.83 \%) \\
\end{array}$ & $\begin{array}{r}630 \\
(90.00 \%) \\
\end{array}$ & $\begin{array}{r}356 \\
(91.04 \%) \\
\end{array}$ & $\begin{array}{r}274 \\
(88.67 \%) \\
\end{array}$ & 0.041 \\
\hline
\end{tabular}
after using the toilet/latrine

Physical Activity

\begin{tabular}{|c|c|c|c|c|c|c|c|}
\hline $\begin{array}{l}\text { Students who were physically active for a total of at least } 60 \\
\text { minutes per day on all } 7 \text { days during the past } 7 \text { days }\end{array}$ & $\begin{array}{r}497 \\
(66.17 \%)\end{array}$ & $\begin{array}{r}259 \\
(65.07 \%)\end{array}$ & $\begin{array}{r}238 \\
(67.04 \%)\end{array}$ & $\begin{array}{r}475 \\
(67.85 \%)\end{array}$ & $\begin{array}{r}261 \\
(66.92 \%)\end{array}$ & $\begin{array}{r}214 \\
(69.48 \%)\end{array}$ & 0.448 \\
\hline $\begin{array}{l}\text { Students who spent three or more hours per day sitting and } \\
\text { watching or doing other sitting activities }\end{array}$ & $\begin{array}{r}109 \\
(14.45 \%) \\
\end{array}$ & $\begin{array}{r}57 \\
(14.35 \%) \\
\end{array}$ & $\begin{array}{r}52 \\
(14.64 \%) \\
\end{array}$ & $\begin{array}{r}117 \\
(16.71 \%) \\
\end{array}$ & $\begin{array}{r}74 \\
(18.9 \%) \\
\end{array}$ & $\begin{array}{r}43 \\
(13.91 \%) \\
\end{array}$ & 0.243 \\
\hline \multicolumn{8}{|c|}{ Protective Factors } \\
\hline Students who missed classes or school without permission & $\begin{array}{r}168 \\
(22.28 \%)\end{array}$ & $\begin{array}{r}76 \\
(19.04 \%)\end{array}$ & $\begin{array}{r}92 \\
(25.91 \%)\end{array}$ & $\begin{array}{r}155 \\
(22.14 \%)\end{array}$ & $\begin{array}{r}87 \\
(22.25 \%)\end{array}$ & $\begin{array}{r}68 \\
(22.00 \%)\end{array}$ & 0.883 \\
\hline $\begin{array}{l}\text { Students who reported that most of the students in their } \\
\text { school were never or rarely kind and helpful }\end{array}$ & $\begin{array}{r}280 \\
(37.23 \%) \\
\end{array}$ & $\begin{array}{r}148 \\
(37.18 \%) \\
\end{array}$ & $\begin{array}{r}132 \\
(37.28 \%) \\
\end{array}$ & $\begin{array}{r}310 \\
(44.41 \%) \\
\end{array}$ & $\begin{array}{r}166 \\
(42.46 \%) \\
\end{array}$ & $\begin{array}{r}144 \\
(46.90 \%) \\
\end{array}$ & 0.005 \\
\hline $\begin{array}{l}\text { students whose parents or guardians never or rarely really } \\
\text { knew what they were doing with their free time }\end{array}$ & $\begin{array}{r}287 \\
(38.06 \%) \\
\end{array}$ & $\begin{array}{r}145 \\
(36.34 \%) \\
\end{array}$ & $\begin{array}{r}142 \\
(40 \%) \\
\end{array}$ & $\begin{array}{r}303 \\
(43.28 \%) \\
\end{array}$ & $\begin{array}{r}161 \\
(41.18 \%) \\
\end{array}$ & $\begin{array}{r}142 \\
(45.95 \%) \\
\end{array}$ & 0.044 \\
\hline \multicolumn{8}{|c|}{ Tobacco Use } \\
\hline Students who smoked cigarettes on one or more days & $\begin{array}{r}16 \\
(2.12 \%) \\
\end{array}$ & $\begin{array}{r}7 \\
(1.75 \%) \\
\end{array}$ & $\begin{array}{r}9 \\
(2.53 \%) \\
\end{array}$ & $\begin{array}{r}16 \\
(2.28 \%) \\
\end{array}$ & $\begin{array}{r}5 \\
(1.27 \%) \\
\end{array}$ & $\begin{array}{r}11 \\
(3.55 \%) \\
\end{array}$ & 0.831 \\
\hline $\begin{array}{l}\text { Students who used any tobacco products other than } \\
\text { cigarettes on one or more days }\end{array}$ & $\begin{array}{c}18 \\
(2.38 \%) \\
\end{array}$ & $\begin{array}{c}9 \\
(2.26 \%) \\
\end{array}$ & $\begin{array}{c}9 \\
(2.53 \%) \\
\end{array}$ & $\begin{array}{c}20 \\
(2.85 \%) \\
\end{array}$ & $\begin{array}{c}9 \\
(2.30 \%) \\
\end{array}$ & $\begin{array}{c}11 \\
(3.55 \%)\end{array}$ & 0.574 \\
\hline $\begin{array}{l}\text { Students who reported people smoking in their presence on } \\
\text { one or more days during the past } 7 \text { days }\end{array}$ & $\begin{array}{r}230 \\
(30.5 \%)\end{array}$ & $\begin{array}{r}123 \\
(30.9 \%)\end{array}$ & $\begin{array}{r}107 \\
(30.14 \%)\end{array}$ & $\begin{array}{r}209 \\
(29.85 \%)\end{array}$ & $\begin{array}{r}121 \\
(30.94 \%)\end{array}$ & $\begin{array}{r}88 \\
(28.47 \%)\end{array}$ & 0.803 \\
\hline
\end{tabular}

Mental health

\begin{tabular}{|c|c|c|c|c|c|c|c|}
\hline $\begin{array}{l}\text { Students who have been so worried about something that } \\
\text { they wanted to use alcohol never or rarely alcohol or other } \\
\text { drugs to feel better }\end{array}$ & $\begin{array}{r}724 \\
(96.02 \%)\end{array}$ & $\begin{array}{r}383 \\
(95.98 \%)\end{array}$ & $\begin{array}{r}341 \\
(96.05 \%)\end{array}$ & $\begin{array}{r}668 \\
(95.42 \%)\end{array}$ & $\begin{array}{r}370 \\
(95.12 \%)\end{array}$ & $\begin{array}{r}298 \\
(96.75 \%)\end{array}$ & 0.763 \\
\hline $\begin{array}{l}\text { Students who were taught in any of their classes how to } \\
\text { handle stress in healthy ways during this school year }\end{array}$ & $\begin{array}{r}472 \\
(62.59 \%) \\
\end{array}$ & $\begin{array}{r}247 \\
(62.06 \%)\end{array}$ & $\begin{array}{r}225 \\
(63.38 \%) \\
\end{array}$ & $\begin{array}{r}386 \\
(55.14 \%)\end{array}$ & $\begin{array}{r}235 \\
(60.25 \%) \\
\end{array}$ & $\begin{array}{r}151 \\
(49.18 \%)\end{array}$ & 0.003 \\
\hline \multicolumn{8}{|c|}{ Violence And Unintentional Injury } \\
\hline $\begin{array}{l}\text { students who were taught how to avoid being bullied in their } \\
\text { classes }\end{array}$ & $\begin{array}{r}399 \\
(52.9 \%)\end{array}$ & $\begin{array}{r}399 \\
(100 \%)\end{array}$ & $0(0 \%)$ & $\begin{array}{r}391 \\
(55.85 \%)\end{array}$ & $\begin{array}{r}391 \\
(100 \%)\end{array}$ & $\begin{array}{r}0 \\
(0 \%)\end{array}$ & 0.260 \\
\hline $\begin{array}{l}\text { students who reported that they had serious injury happened } \\
\text { to them }\end{array}$ & $\begin{array}{r}466 \\
(61.80 \%)\end{array}$ & $\begin{array}{r}227 \\
(56.89 \%)\end{array}$ & $\begin{array}{r}239 \\
(67.32 \%)\end{array}$ & $\begin{array}{r}463 \\
(66.14 \%)\end{array}$ & $\begin{array}{r}237 \\
(60.61 \%)\end{array}$ & $\begin{array}{r}226 \\
(73.13 \%)\end{array}$ & 0.077 \\
\hline \multicolumn{8}{|c|}{ Alcohol Use Module } \\
\hline $\begin{array}{l}\text { students who have been taught dangers of alcohol use in } \\
\text { school year }\end{array}$ & $\begin{array}{r}327 \\
(43.36 \%)\end{array}$ & $\begin{array}{r}174 \\
(43.60 \%)\end{array}$ & $\begin{array}{r}153 \\
(43.09 \%)\end{array}$ & $\begin{array}{r}326 \\
(46.57 \%)\end{array}$ & $\begin{array}{r}188 \\
(48.08 \%)\end{array}$ & $\begin{array}{r}138 \\
(44.66 \%)\end{array}$ & 0.192 \\
\hline $\begin{array}{l}\text { students who reported that parents or guardians drink } \\
\text { alcohol }\end{array}$ & $\begin{array}{r}153 \\
(20.29 \%) \\
\end{array}$ & $\begin{array}{r}75 \\
(18.79 \%) \\
\end{array}$ & $\begin{array}{r}78 \\
(21.97 \%) \\
\end{array}$ & $\begin{array}{r}114 \\
(16.28 \%) \\
\end{array}$ & $\begin{array}{r}70 \\
(17.90 \%) \\
\end{array}$ & $\begin{array}{r}44 \\
(14.32 \%) \\
\end{array}$ & 0.053 \\
\hline \multicolumn{8}{|c|}{ Drugs Use Module } \\
\hline $\begin{array}{l}\text { students during the past } 12 \text { months, how much times have } \\
\text { they used drugs }\end{array}$ & $\begin{array}{r}23 \\
(3.05 \%)\end{array}$ & $\begin{array}{r}10 \\
(2.50 \%)\end{array}$ & $\begin{array}{r}13 \\
(3.66 \%)\end{array}$ & $\begin{array}{r}25 \\
(3.57 \%)\end{array}$ & $\begin{array}{r}17 \\
(4.34 \%)\end{array}$ & $\begin{array}{r}8 \\
(2.58 \%)\end{array}$ & 0.574 \\
\hline $\begin{array}{l}\text { students during their school year, who taught in any of their } \\
\text { classes the problems associated with using drugs }\end{array}$ & $\begin{array}{r}281 \\
(37.26 \%) \\
\end{array}$ & $\begin{array}{r}145 \\
(36.34 \%) \\
\end{array}$ & $\begin{array}{r}136 \\
(38.30 \%) \\
\end{array}$ & $\begin{array}{r}255 \\
(36.42 \%) \\
\end{array}$ & $\begin{array}{r}138 \\
(35.29 \%) \\
\end{array}$ & $\begin{array}{r}117 \\
(37.86 \%) \\
\end{array}$ & 0.756 \\
\hline \multicolumn{8}{|c|}{ Sexual Behavior Module } \\
\hline students & 271 & 126 & 145 & 320 & 168 & 152 & 0.0001 \\
\hline
\end{tabular}




\begin{tabular}{|c|c|c|c|c|c|c|c|}
\hline infection or AIDS in sch & $(35.94 \%)$ & $(31.57 \%)$ & $(40.84 \%)$ & $(45.71 \%)$ & $(42.96 \%)$ & $(49.19 \%)$ & \\
\hline students who heard of HIV infections or AIDS & $\begin{array}{r}394 \\
(52.25 \%) \\
\end{array}$ & $\begin{array}{r}199 \\
(49.87 \%) \\
\end{array}$ & $\begin{array}{r}195 \\
(54.92 \%) \\
\end{array}$ & $\begin{array}{r}383 \\
(54.71 \%) \\
\end{array}$ & $\begin{array}{r}201 \\
(51.40 \%) \\
\end{array}$ & $\begin{array}{r}182 \\
(58.89 \%) \\
\end{array}$ & 0.430 \\
\hline $\begin{array}{l}\text { students who were taught in any of their classes how to } \\
\text { avoid HIV infection or AIDS in school year }\end{array}$ & $\begin{array}{r}251 \\
(33.28 \%)\end{array}$ & $\begin{array}{r}123 \\
(30.82 \%)\end{array}$ & $\begin{array}{r}128 \\
(36.05 \%)\end{array}$ & $\begin{array}{r}251 \\
(35.85 \%)\end{array}$ & $\begin{array}{r}134 \\
(34.27 \%)\end{array}$ & $\begin{array}{r}117 \\
(37.86 \%)\end{array}$ & 0.292 \\
\hline $\begin{array}{l}\text { students who } \\
\text { talked about HIV infection or AIDS with their parents or } \\
\text { guardians }\end{array}$ & $\begin{array}{r}168 \\
(22.28 \%)\end{array}$ & $\begin{array}{r}70 \\
(17.54 \%)\end{array}$ & $\begin{array}{r}98 \\
(27.60 \%)\end{array}$ & $\begin{array}{r}159 \\
(22.71 \%)\end{array}$ & $\begin{array}{r}72 \\
(18.41 \%)\end{array}$ & $\begin{array}{r}87 \\
(28.15 \%)\end{array}$ & 0.830 \\
\hline $\begin{array}{l}\text { students who reported that neatly looking person can be } \\
\text { infected with HIV }\end{array}$ & $\begin{array}{r}174 \\
(23.07 \%)\end{array}$ & $\begin{array}{r}86 \\
(21.55 \%)\end{array}$ & $\begin{array}{r}88 \\
(24.78 \%)\end{array}$ & $\begin{array}{r}213 \\
(30.42 \%)\end{array}$ & $\begin{array}{r}120 \\
(30.69 \%)\end{array}$ & $\begin{array}{r}93 \\
(30.09 \%)\end{array}$ & 0.001 \\
\hline
\end{tabular}

